\begin{tabular}{cc|c}
\hline Tar. Bil. Der. & Journal of Agricultural Sciences \\
& $\begin{array}{c}\text { Dergi web sayfası: } \\
\text { www.agri.ankara.edu.tr/dergi }\end{array}$ & Journal homepage: \\
& www.agri.ankara.edu.tr/journal
\end{tabular}

\title{
Identification of Barley Landraces and Wild Barley (Hordeum spontaneum) Genotypes Resistant to Rhynchosporium commune
}

\author{
Mohammad Reza AZAMPARSA ${ }^{\mathrm{a}}$, Aziz KARAKAYA ${ }^{\mathrm{b}}$, Namuk ERGÜNc ${ }^{\mathrm{c}}$, Ísmail SAYİMc, Rukiye MURAT \\ DURAN ${ }^{c}$, Kürşad ÖZBEK ${ }^{c}$ \\ ${ }^{a}$ University of Maragheh, Faculty of Agriculture, Department of Plant Protection, Maragheh, IRAN \\ ${ }^{b}$ Ankara University, Faculty of Agriculture, Department of Plant Protection, Dişkapl, Ankara, TURKEY \\ ${ }^{c}$ Central Research Institute for Field Crops, Yenimahalle, Ankara, TURKEY
}

\author{
ARTICLE INFO \\ Research Article \\ Corresponding Author: Aziz KARAKAYA, E-mail: karakaya@agri.ankara.edu.tr, Tel: +90 (312) 5961258 \\ Received: 09 July 2018, Received in Revised Form: 23 October 2018, Accepted: 04 November 2018
}

\begin{abstract}
Barley scald is caused by the fungal pathogen Rhynchosporium commune. This disease causes substantial losses in barley production areas of the world. In this study, seedling resistance of 198 barley landraces, 104 wild barley (Hordeum spontaneum) genotypes and two susceptible Turkish cultivars (Bülbül 89 and Efes 3 ) to 6 R. commune isolates was assessed in greenhouse experiments. Virulence differences among the $R$. commune isolates were observed. One sixrowed barley landrace (Yeşilköy 9052) was resistant to all six isolates. Another six-rowed barley landrace (genotype no 17) showed resistant reaction to 5 isolates. Fourteen barley landraces were resistant and susceptible to 4 and 2 isolates, respectively. Twenty seven genotypes of $H$. spontaneum numbered as 5, 6, 7, 8, 9, 11, 16, 20, 30, 31, 36, 37, 48, 50, 51, $56,58,59,60,62,67,79,80,83,90,94$ and 101 were found resistant to all six isolates of $R$. commune. Apart from these genotypes, 19 genotypes numbered as $1,2,32,33,34,42,43,49,52,64,66,76,77,78,96,97,102,104$ and 107 showed resistance to 5 isolates and susceptibility to only 1 isolate. Two susceptible Turkish cultivars Bülbül 89 and Efes 3 were found susceptible to $96 \%$ of the scald isolates. Resistant barley landraces and Hordeum spontaneum genotypes can be used as sources of resistance against $R$. commune.
\end{abstract}

Keywords: Scald; Rhynchosporium commune; Barley landraces; Wild barley; Hordeum spontaneum; Disease resistance

(C) Ankara Üniversitesi Ziraat Fakültesi

\section{Introduction}

Rhynchosporium commune (formerly known as Rhynchosporium secalis) (Zaffarano et al 2011) is a haploid pathogen that attack different barley species including cultivated and wild barley. This pathogen can attack to barley plants and produce disease symptoms on leaves, leaf sheaths and ears of barley (Avora \& Knogge 2012). The disease is common in the world and disease losses on cultivated barley due to this pathogen have been reported from $10 \%$ to $70 \%$ (Shipton et al 1974; Eshetu 1985; Zhang et al 1992; Sheikh Jabbari 2008; Karakaya et al 2014). Control of barley scald disease is achieved by a variety of control measures including chemical, agronomical and biological control methods. Using resistant cultivars, due to environmentally friendly implementation of this control method, is desirable. 
However, to obtain scald disease resistance sources in barley, extensive studies of both fungus pathogenicity and barley cultivars/lines screening for resistance are required. Turkey is considered as one of the precious gene pools of barley including disease resistance sources in Fertile Crescent (Kün 1996; Badr et al 2000; Karakaya et al 2016). Barley landraces and wild barleys are important sources of genetic variation and disease resistance (Yitbarek et al 1998; Ceccarelli \& Grando 2000; Ellis et al 2000). Barley landraces and wild barley (H. spontaneum) genotypes are widely distributed in Turkey (Kün 1996; Badr et al 2000; Karakaya et al 2016; Ergün et al 2017). Due to rich heritage of barley landraces and wild barley (H. spontaneum) genotypes in different sites of Turkey, finding new sources of scald disease resistance using barley landraces and wild barley genotypes and transferring resistance traits into cultivated barley could have a great value in scald disease resistance studies. In this study, seedling reactions of 198 barley landraces and 104 wild barley (H. spontaneum) genotypes were determined using $6 R$. commune isolates.

\section{Material and Methods}

\subsection{Plant materials}

Two hundred barley landraces and 107 Hordeum spontaneum genotypes were obtained from Central Research Institute for Field Crops located in Ankara, Turkey. These barley landraces and wild barley seeds were multiplied in the field for use in this study and in future studies. In the seed propagation process insufficient seeds were obtained from barley landraces no. 43 and no. 116 and wild barley genotypes numbered as 4,15 and 41 and therefore, they were not used in the experiments.

\subsection{Rhynchosporium commune isolates}

Six Rhynchosporium commune isolates [(4 most virulent isolates (GPS 71-U, 13GPS203, 13GPS207 and 13GPS 109), one isolate with high virulence value (13GPS149) and 1 isolate representing the most common pathotype (E4)] selected from Azamparsa (2015) study were used in determination of seedling stage resistance of 198 barley landraces, $104 \mathrm{H}$. spontaneum genotypes and susceptible Turkish cultivars Bülbül 89 and Efes 3 under greenhouse conditions. Isolates GPS 71-U, 13GPS203, 13GPS207, 13GPS109, 13GPS149 and E4 were obtained from Gaziantep-Subağ 1 , Manisa-Kula, İzmir-Bergama, Ankara-Şereflikoçhisar, MardinMidyat and Eskişehir-Tepebaşı regions of Turkey, respectively (Azamparsa 2015).

\subsection{Making single spore isolates, inoculation, incubation and disease assessment}

Infected leaf samples obtained from different regions of Turkey were cut into small sizes, surface sterilized with $70 \%$ ethyl alcohol in 15 seconds followed by $0.5 \%$ sodium hypochlorite in 90 seconds and placed on sterilized filter paper for 1 minute (Azamparsa 2015). These dried samples were placed on autoclaved Bean Agar (BA) medium (140 $\mathrm{g}$ fresh bean, $20 \mathrm{~g}$ dextrose, $18 \mathrm{~g}$ agar, $1 \mathrm{~L}$ distilled water) at $22{ }^{\circ} \mathrm{C}$ inside an incubator. Fungus colony was produced on this medium after 2-3 weeks. To obtain single spore of fungus, $1 \mathrm{~mL}$ of sterile water was placed in a small micro tube and by using a sterile needle small part of colony with spores was transferred into the micro tube. This micro tube was shaken well and with the use of a sterile loop spore suspension was dispersed on BA medium. After 2-3 days under a stereomicroscope germinated spores were taken to the other Petri dishes containing BA. Developed colonies of single spores were transformed to test tubes containing BA medium and stored at $4{ }^{\circ} \mathrm{C}$ in a refrigerator. To produce inoculum, each isolate was grown on BA medium for about 14 days and then distilled water was added onto this colony and spores were harvested. Harvested spore suspension was cleaned from large parts of colonies using a cheesecloth and spore concentration was adjusted to $1 \times 10^{6}$ spores $\mathrm{mL}^{-1}$. One drop of Tween-20 was added to each 100 $\mathrm{mL}$ of inoculum. Five to 10 seeds of each genotype were seeded to $7 \mathrm{~cm}$ diameter plastic pots. These pots were placed in the greenhouse and watered when needed. Inoculation of plants was made when plants produced 1.5 leaves. After inoculation, plants 
were transferred inside of a moist chamber with $100 \%$ relative humidity and $16-17{ }^{\circ} \mathrm{C}$ temperature range for 48 hours to insure infection of plants. After 2 days, plants were taken into the greenhouse with 20-25 ${ }^{\circ} \mathrm{C}$ temperature range. Disease symptoms started 8-10 days after inoculation and first disease assessment was made using El-Ahmed (1981) scale after 14 days of inoculation. The second disease assessment was made four days later (18 days after inoculation) and results of second assessment were used in disease evaluation. Three replications were used. Scale values of $0-2.0$ were considered as resistant reaction and scale values of 2.1-4.0 were considered as susceptible reaction.

\section{Results and Discussion}

Among barley landraces only one genotype (genotype no: 200, Yeşilköy 9052) was resistant to all 6 tested isolates and therefore it was determined as the most resistant genotype. Barley landrace no: 17 was resistant to 5 isolates and moderately susceptible to GPS71-U isolate and this genotype was rated as the second most resistant genotype. Fourteen barley landraces were resistant and susceptible to 4 and 2 isolates, respectively. These barley landraces included the following landraces: $2,15,20,23,24,79,81,82,83,120,121,132,134$ and 194.

Presence of resistance to barley scald in barley landraces and cultivars were reported previously. In Ethiopia, up to 100 single plant derived lines of 18 barley landraces were tested against $R$. commune and it was concluded that on average landraces with late maturity showed more resistance to barley scald (Alemayehu \& Parlevliet 1997). In another study in Ethiopia, 180 barley landraces and 600 single head plants selected from 60 promising populations were evaluated for barley scald disease resistance. Barley landraces from higher altitude were more resistant to $R$. commune (Yitbarek et al 1998). In Spain, Silvar et al (2010) used 159 (148 six-rowed and 11 two-rowed) inbred lines from local landraces and 16 commercial cultivars ( 8 six-rowed and 8 two-rowed) and tested their resistance against several barley diseases including barley scald. They found resistant reaction in about $26 \%$ of Spanish lines (mostly winter barleys) to $R$. commune. In Turkey, some barley genotypes which were bred in breeding programs by Central Research Institute for Field Crops and International Center for Agriculture Research in Dry Areas (ICARDA) were tested against $R$. commune. One thousand and four hundred one and 1379 barley lines and cultivars were evaluated aginst barley scald in the field and greenhoue tests, respectively. From these tested lines and cultivars 432 genotypes in the field and 257 genotypes in the greenhouse were found resistant or moderately resistant to barley scald. From 15 barley cultivars only Erginel 90 cultivar was found resistant to $R$. commune in both field and greenhouse experiments (Albustan et al 1998). In the other experiment by Mert \& Karakaya (2004) both differences for resistance among barley cultivars and pathogenicity among 5 isolates of $R$. commune were found. Among the tested cultivars Çetin 2000, Şahin 91, Erginel 90, Kıral 97, Akhisar 98, Çumra 2001 and Avc1 2002 were found resistant to all isolates. Cultivars Bülbül 89 and Efes 3 were susceptible to barley scald isolates. In another study, reactions of 36 barley cultivars and 683 barley genotypes to $R$. commune were determined in greenhouse and field experiments and from 683 barley genotypes, 44\% in greenhouse and $39 \%$ in field tests were found resistant to $R$. commune (Düşünceli et al 2008). There was significant correlation $(\mathrm{r}=0.53)$ between greenhouse and field test results $(\mathrm{P}=0.0001)$. The cultivars Avcı 2002, Çetin 2000, Kıral 97, Erginel 90, Akhisar 98, Kaya 7794, Yeşilköy 387 and Zafer 160 were found as resistant under both greenhouse and field conditions. The cultivars Vamikhoca, Ç1ldır 02 and Quantum were found as susceptible under greenhouse conditions; however, they were found as resistant under field conditions. Twenty five cultivars were susceptible to barley scald both in greenhouse and field tests. Azamparsa et al (2015a) reported virulence differences among the $R$. commune isolates. Isolate obtained from Gaziantep was the most virulent followed by isolates obtained from Manisa and Eskişehir provinces of Turkey. These results show differences in resistance among barley cultivars and genotypes as well as virulence 
differences among isolates of $R$. commune. Similar results were obtained in our current study.

From 198 barley landraces which were tested in this study, 169 and 29 barley landraces were belonged to 2-rowed and 6-rowed barleys, respectively. While 6-rowed barley cultivars had medium disease value of 2.5 out of 4 , two-rowed barley landraces had disease value of 3.3 out of 4 . Based on these results it can be said that six-rowed barley landraces were more resistant than tworowed barleys to $R$. commune. The same results were reached by many workers in previous studies. In these experiments six-rowed barley cultivars were found more resistant than two-rowed barley cultivars to $R$. commune (Zencirci \& Hayes 1990; Mert \& Karakaya 2004; Düşünceli et al 2008; Silvar et al 2010; Mert et al 2014).

Twenty seven genotypes of wild barley ( $H$. spontaneum) numbered as $5,6,7,8,9,11,16,20$, $30,31,36,37,48,50,51,56,58,59,60,62,67$, $79,80,83,90,94$ and 101 were found resistant to all six isolates of $R$. commune. Apart from these genotypes, 19 genotypes numbered as $1,2,32,33$, $34,42,43,49,52,64,66,76,77,78,96,97,102$, 104 and 107 showed resistance to $5 R$. commune isolates and susceptibility to only 1 isolate.

Genotypes of H. spontaneum are used in breeding programs as resistance sources especially resistance to cold and dry weather and disease resistance (Chen et al 2008; Çelik \& Karakaya 2017). In the current study $26 \%$ of wild barley genotypes showed resistance to barley scald disease in seedling stage. This result shows high potential of wild barley (H. spontaneum) genotypes for resistance to $R$. commune. Resistance genes were successfully transformed from wild barley to cultivated barley (Çelik \& Karakaya 2017). Abbott et al (1992) screened accessions of $H$. vulgare ssp. spontaneum collected from Israel (70), Iran (15) and Turkey (6) against four isolates of $R$. commune in seedling stage and they found a high percentage of resistance (77\%) among these wild barley accessions to barley scald. Cherif et al (2012) in Tunisia tested 56 accessions of wild barleys (H. spontaneum, H. marinum and $H$. murinum) and 7 varieties of $H$. vulgare against net blotch and scald to find new sources of resistance to these diseases and they found sources of resistance to $R$. commune in three wild species of barley. However, due to strong incompatibility between cultivated and two wild barleys (H. marinum and H. murinum) (Pickering \& Johnston 2005), it seems that transfer of scald resistance genes to cultivated barley from $H$. spontaneum is more feasible. In their study, two $H$. spontaneum accessions collected from Afghanistan and Egypt showed resistance to barley scald both in seedling and adult growth stages.

Two susceptible Turkish cultivars Bülbül 89 and Efes 3 used in the current study were found susceptible to $96 \%$ of the scald isolates. Susceptibility of these cultivars were reported previously (Mert \& Karakaya 2004; Azamparsa et al 2015b) and confirmed with this study. Resistant $H$. spontaneum genotypes and barley landraces identified in this study could be used in breeding programs for obtaining scald resistant genotypes or promising landraces could be used directly as the seeding materials.

\section{Conclusions}

In this study only one barley landrace out of 198 landraces (genotype no: 200) $(0.5 \%$ of the genotypes) showed resistance to all six tested isolates to $R$. commune. Another six-rowed barley (genotype no: 17) landrace showed resistant reaction to 5 isolates and moderately susceptible reaction to 1 isolate. Fourteen barley landraces were resistant and susceptible to 4 and 2 isolates, respectively. Twenty seven lines of wild barley (H. spontaneum) out of 104 genotypes were resistant to all 6 isolates of $R$. commune. In addition, 19 genotypes showed resistance to 5 isolates and susceptibility to only 1 isolate. Resistance to $R$. commune among barley landraces was low. On the other hand, more wild barley (H. spontaneum) genotypes were resistant to $R$. commune. It appears that Hordeum spontaneum genotypes are good resistance sources of scald disease of barley caused by $R$. commune. 


\section{Acknowledgements}

This study is financially supported by The Scientific and Technological Research Council of Turkey (Project No: 111O644).

\section{References}

Abbott D C, Burdon J J \& Brown A H D (1992). Genes for scald resistance from wild barley (Hordeum vulgare ssp. spontaneum) and their linkage to isozyme markers. Euphytica 61: 225-231

Albustan S, Çetin L \& Düşünceli F (1998). Orta Anadolu için geliştirilen bazı arpa nörserilerinde arpa yaprak lekesi hastalığına (Rhynchosporium commune (Oudem.) J.J. Davis) dayanıklı genotiplerin sera ve tarla koşullarında belirlenmesi. Türkiye VIII. Fitopatoloji Kongresi Bildirleri, 21-25 Eylül, Ankara, pp. 30-33

Alemayehu F \& Parlevliet J E (1997). Variation between and within Ethiopian barley landraces. Euphytica 94: 183-189

Avora A \& Knogge W (2012). Rhynchosporium commune: a persistent threat to barley cultivation. Molecular Plant Pathology 13: 986-997

Azamparsa M R (2015). Türkiye'de Rhynchosporium commune'nin patotiplerinin belirlenmesi ve bazı yerel arpa çeşitlerine ve yabani arpa (Hordeum spontaneum) populasyonlarına karş1 tepkilerinin değerlendirilmesi. Doktora Tezi. Ankara Üniversitesi Fen Bilimleri Enstitüsü

Azamparsa M R, Karakaya A, Mert Z, Aydın G, Peşkircioğlu H, Seçer E, Özmen D, Tutluer İ \& Sağel Z (2015a). Seedling response of two barley cultivars and gamma ray-induced advanced barley lines to Rhynchosporium commune. Tarla Bitkileri Merkez Araştırma Enstitüsü Dergisi 24(1): 75-78

Azamparsa M R, Mert Z, Karakaya A, Sayim İ, Ergün N \& Aydoğan S (2015b). Determination of the seedling reactions of some barley cultivars and advanced barley lines to Rhynchosporium commune. Bitki Koruma Bülteni 55(3): 247-252

Badr A, Müller K, Schafer-Pregl R, El Rabey H, Effgen S, Ibrahim H H, Pozzi C, Rohde W \& Salamini F (2000). On the origin and domestication history of barley (Hordeum vulgare). Molecular Biology and Evolution 17: 499-510

Ceccarelli S \& Grando S (2000). Barley landraces from the Fertile Crescent. A lesson for plant breeders.
In: S. B. Brush (Ed.), Genes in the Field, On-farm Conservation of Crop Diversity, Int. Plant Gen. Res. Institute, International Developmet Research Center, Lewis Publishers, Boca Raton, London, New York, Washington, D.C., pp. 51-76

Chen G, Li C, Shi Y \& Nevo E (2008). Wild barley, Hordeum spontaneum, a genetic resource for crop improvement in cold and arid regions. Science in Cold and Arid Regions 1: 115-124

Cherif M, Chaouachi D, Feriani W \& Rezgui S (2012). Resistance to wild barley (Hordeum spontaneum, $H$. marinum, and H. murinum) to Pyrenophora teres and Rhynchosporium secalis causing net blotch and scald diseases in Tunisia. International Journal of Plant Breeding 6(2): 89-94

Çelik E \& Karakaya A (2017). Yabani arpa (Hordeum spontaneum) ve hastal1klara dayanıkl1l1k. Mustafa Kemal Üniversitesi Ziraat Fakültesi Dergisi 22: 6586

Düşünceli F, Çetin L, Albustan S, Mert Z, Akan K \& Karakaya A (2008). Determination of the reactions of some barley cultivars and genotypes to scald under greenhouse and field conditions. Tarm Bilimleri Dergisi 14(1): 46-50

El-Ahmed A M (1981). Seedling reaction of the $7^{\text {th }}$ IBON to $R$. secalis in the greenhouse and source of resistance. Barley Diseases and Associated Breeding Methodology Workshop. Rabat, Morocco

Ellis R P, Forster B P, Robinson D, Handley L L, Gordon D C, Russell J R \& Powell W (2000). Wild barley: a source of genes for crop improvement in the $21^{\text {st }}$ century? Journal of Experimental Botany 51(342): 9-17

Ergün N, Aydoğan S, Sayim İ, Karakaya A \& Çelik Oğuz A (2017). Arpa (Hordeum vulgare L.) köy çeşitlerinde tane verimi ve bazı tarımsal özelliklerin incelenmesi. Tarla Bitkileri Merkez Araştırma Enstitüsü Dergisi 26(2): 180-189

Eshetu B (1985). A review of research on diseases of barley, tef and wheat in Ethiopia. In: A. Tsedeke (Ed.), A Review of Crop Protection Research in Ethiopia. Institute of Agricultural Research, Addis Ababa, Ethiopia, pp. 79-108

Karakaya A, Mert Z, Çelik Oğuz A, Azamparsa M R, Çelik E, Akan K \& Çetin L (2014). Current status of scald and net blotch diseases of barley in Turkey. In: Proceedings of 1st International Workshop on Barley 
Leaf Diseases, June 3-6, Salsomaggiore Terme, Italy, pp. 31

Karakaya A, Mert Z, Çelik Oğuz A, Ertaş M N \& Karagöz A (2016). Determination of the diseases occurring on naturally growing wild barley (Hordeum spontaneum) field populations. Works of the Faculty of Agriculture and Food Sciences, University of Sarajevo 61, 66/1: 291-295

Kün E (1996). Tahıllar-1 (Serin İklim Tahılları). Ankara Üniversitesi Ziraat Fakültesi Yayınları,Yayın No: 1451. Ankara

Mert Z \& Karakaya A (2004). Assessment of the seedling reactions of Turkish barley cultivars to scald. Journal of Phytopathology 152: 190-192

Mert Z, Karakaya A, Çelik Oğuz A, Azamparsa M R, Ergün N \& Sayim İ (2014). Field evaluation of some Turkish barley landraces to scald and net blotch of barley. In: Proceedings of $1^{\text {st }}$ International Workshop on Barley Leaf Diseases, June 3-6, Salsomaggiore Terme, Italy, pp. 64

Pickering R \& Johnston P A (2005). Recent progress in barley improvement using wild species of Hordeum. Cytogenetic and Genome Research 109: 344-349

Sheikh Jabbari J (2008). Molecular characterisation of differentially expressed genes in the interaction of barley and Rhynchosporium secalis. $\mathrm{PhD}$ Thesis. University of Adelaide, Australia

Shipton W A, Boyd W J R \& Ali S M (1974). Scald of barley. Review of Plant Pathology 53: 839-861

Silvar C, Casas A M, Kopahnke D, Habekub A, Schweizer G, Gracia M P, Lasa J M, Ciudad F J, Molina-Cano J L, Igartua E \& Ordon F (2010). Screening the Spanish barley core collection for disease resistance. Plant Breeding 129(1): 45-52

Yitbarek S, Berhane L, Fikadu A, Van Leour J A G, Grando S \& Ceccarelli S (1998). Variation in Ethiopian barley landrace populations for resistance to barley leaf scald and net blotch. Plant Breeding 117: 419-423

Zaffarano P L, McDonald B A \& Linde C C (2011). Two new species of Rhynchosporium. Mycologia 103(1): 195-202

Zencirci N \& Hayes P M (1990). Effects of scald (Rhynchosporium secalis) on yield and yield components of twelve winter barley (Hordeum vulgare) genotypes. Journal of Turkish Phytopathology 19(3): 119-132

Zhang Q, Webster R K, Crandall B A, Jackson L F \& Saghai Maroof M A (1992). Race composition and pathogenicity associations of Rhynchosporium secalis in California. Phytopathology 82: 798-803 